\title{
PENINGKATAN KESELAMATAN JALAN \\ PADA BLACK SPOT JALAN PROVINSI DI KABUPATEN SLEMAN
}

\author{
One Sigit Hermanto \\ MSTT FT UGM \\ Jln. Grafika 2, Kampus UGM \\ Sleman 55281 \\ one.hermanto@jogjaprov.go.id
}

\author{
Agus Taufik Mulyono \\ DTSL FT UGM/PUSTRAL UGM \\ Jln. Kemuning M3, Sekip, Mlati \\ Sleman 55281 \\ agus.taufik.mulyono@ugm.ac.id
}

\author{
Latif Budi Suparma \\ MSTT FT UGM \\ Jln. Grafika 2, Kampus UGM \\ Sleman 55281 \\ lbsuparma@ugm.ac.id
}

\begin{abstract}
The fatality rate of traffic accidents in Sleman Regency is increasing every year. This study aims to identify black spots and set priorities for repairing road infrastructure components needed to improve road safety on 3 provincial roads in Sleman Regency. The black spot is determined using the Accident Equivalence Number Method and the Upper Control Limit. The evaluation carried out resulted in the 3 worst segments on each observed road segment. The results of the road safety evaluation show that the technical implementation of traffic management and engineering, the technical use of road components, and the technicality of road equipment are the 3 technical requirements of the road with the lowest level of application. To improve road safety, this study recommends adding rumble strips, adding signs, relocating roadside hazards, and adding sidewalks and crossing zones.
\end{abstract}

Keywords: fatality; black spots; traffic accident; road; road safety.

\begin{abstract}
Abstrak
Tingkat fatalitas kecelakaan lalu lintas di Kabupaten Sleman meningkat setiap tahun. Penelitian ini bertujuan untuk mengidentifikasi black spot dan menetapkan prioritas perbaikan komponen infrastruktur jalan yang diperlukan untuk meningkatkan keselamatan jalan di 3 ruas jalan provinsi di Kabupaten Sleman. Black spot ditentukan dengan menggunakan Metode Angka Ekivalensi Kecelakaan dan Batas Kontrol Atas. Evaluasi yang dilakukan menghasilkan 3 segmen terburuk pada setiap ruas jalan yang diamati. Hasil evaluasi keselamatan jalan menunjukkan bahwa teknis penyelenggaraan manajemen dan rekayasa lalu lintas, teknis pemanfaatan bagian-bagian jalan, dan teknis perlengkapan jalan merupakan 3 persyaratan teknis jalan dengan tingkat penerapan terendah. Untuk meningkatkan keselamatan jalan, studi ini merekomendasikan penambahan rumble strip, penambahan rambu, merelokasi hazard yang terdapat di tepi jalan, serta penambahan trotoar dan zona penyeberangan.
\end{abstract}

Kata-kata kunci: fatalitas; black spot; kecelakaan lalu lintas; jalan; keselamatan jalan.

\section{PENDAHULUAN}

Jumlah kecelakaan lalu lintas di Kabuaten Sleman cenderung meningkat sepanjang waktu. Salah satu strategi Pemerintah dalam mengurangi angka kecelakaan lalu lintas ialah dengan menetapkan Rencana Umum Nasional Keselamatan (RUNK) Jalan tahun 2011-2035, yang tertuang dalam Inpres No. 4 tahun 2013. RUNK menerangkan 5 pilar peningkatan keselamatan lalu lintas dan angkutan jalan, yang salah satunya adalah Pilar-2, yaitu jalan yang berkeselamatan (safer road). 
Kementerian Pekerjaan Umum, sebagai koordinator Pilar-2, mencanangkan 7 program jalan yang berkeselamatan, yaitu badan jalan yang berkeselamatan, perencanaan dan pelaksanaan pekerjaan jalan yang berkeselamatan, perencanaan dan pelaksanaan perlengkapan jalan, penerapan manajemen kecepatan, peningkatan standar kelaikan jalan yang berkeselamatan, lingkungan jalan yang berkeselamatan, dan kegiatan tepi jalan yang berkeselamatan. Dari aspek perundang-undangan, Indonesia telah memiliki regulasi yang mengamanatkan pembangunan dan pengelolaan jalan yang berkeselamatan, yaitu Undang-Undang No. 38 tahun 2004, Tentang Jalan, dan diikuti oleh Peraturan Pemerintah No. 34 tahun 2006, Tentang Jalan. Sedangkan pada aspek manajemen dan sistem lalu lintas, Pemerintah telah menerbitkan Peraturan Pemerintah Nomor 37 Tahun 2017, tentang Keselamatan Lalu Lintas dan Angkutan Jalan.

Sesuai amanat perundangan, peninjauan aspek keselamatan dilakukan pada keseluruhan proyek infrastruktur, dimulai pada studi pra-kelayakan hingga tahap pemeliharaan dan evaluasi. Kegiatan nyata, dalam rangka upaya peningkatan keselamatan jalan, pada tiap tahapan proyek tersebut diwujudkan dalam beberapa model atau metode evaluasi keselamatan, yang di antaranya adalah Inspeksi Keselamatan Jalan (IKJ), Audit Keselamatan Jalan (AKJ), dan Uji Laik Fungsi Jalan (ULFJ).

Peninjauan aspek keselamatan jalan jalan nasional dalam beberapa tahun terakhir terus meningkat. Tetapi hal tersebut tidak diimbangi oleh jalan dengan status jalan provinsi dan jalan kabupaten atau jalan kota, termasuk dalam hal ini jalan provinsi di Daerah Istimewa Yogyakarta (DIY). Data kecelakaan lalu lintas menunjukkan jumlah kecelakaan yang terjadi di DIY cukup tinggi dan cenderung mengalami peningkatan jumlah seiring waktu (Bappeda DIY, 2020). Data BPS tahun 2017 menunjukkan bahwa kabupaten Sleman merupakan wilayah dengan tingkat keparahan akibat kecelakaan yang tertinggi di DIY, yaitu sebesar 39,1 \% terhadap jumlah korban jiwa akibat kecelakaan lalu lintas di seluruh DIY. Data Bidang Bina Marga DIY di tahun 2019 menunjukkan bahwa ruas-ruas jalan provinsi di Sleman menempati peringkat teratas pada jumlah Lalu Lintas Harian Rata-rata (LHR) dibandingkan keseluruhan ruas jalan provinsi di DIY. Artinya, eksposur lalu lintas yang tinggi di wilayah ini berpotensi memiliki risiko terjadinya kecelakaan lalu lintas yang tinggi pula.

Studi ini bertujuan untuk mengidentifikasi titik-titik rawan kecelakaan dan menganalisis tingkat penerapan persyaratan teknis jalan yang berpotensi menjadi penyebab terjadinya kecelakaan lalu lintas. Selain itu, dilakukan analisis terhadap komponen infrastruktur jalan yang perlu ditingkatkan atau diperbaiki pada segmen terburuk di jalan provinsi di Kabupaten Sleman.

\section{METODOLOGI PENELITIAN}

Studi ini terdiri atas beberapa tahapan yang tersusun secara berurutan. Tahapan studi ini meliputi Tahap Persiapan, Tahap Kompilasi Data Sekunder, Tahap Kompilasi Data 
Primer, Tahap Analisis dan Pembahasan, dan Tahap Rekomendasi. Tahapan tersebut dapat dilihat pada Gambar 1.
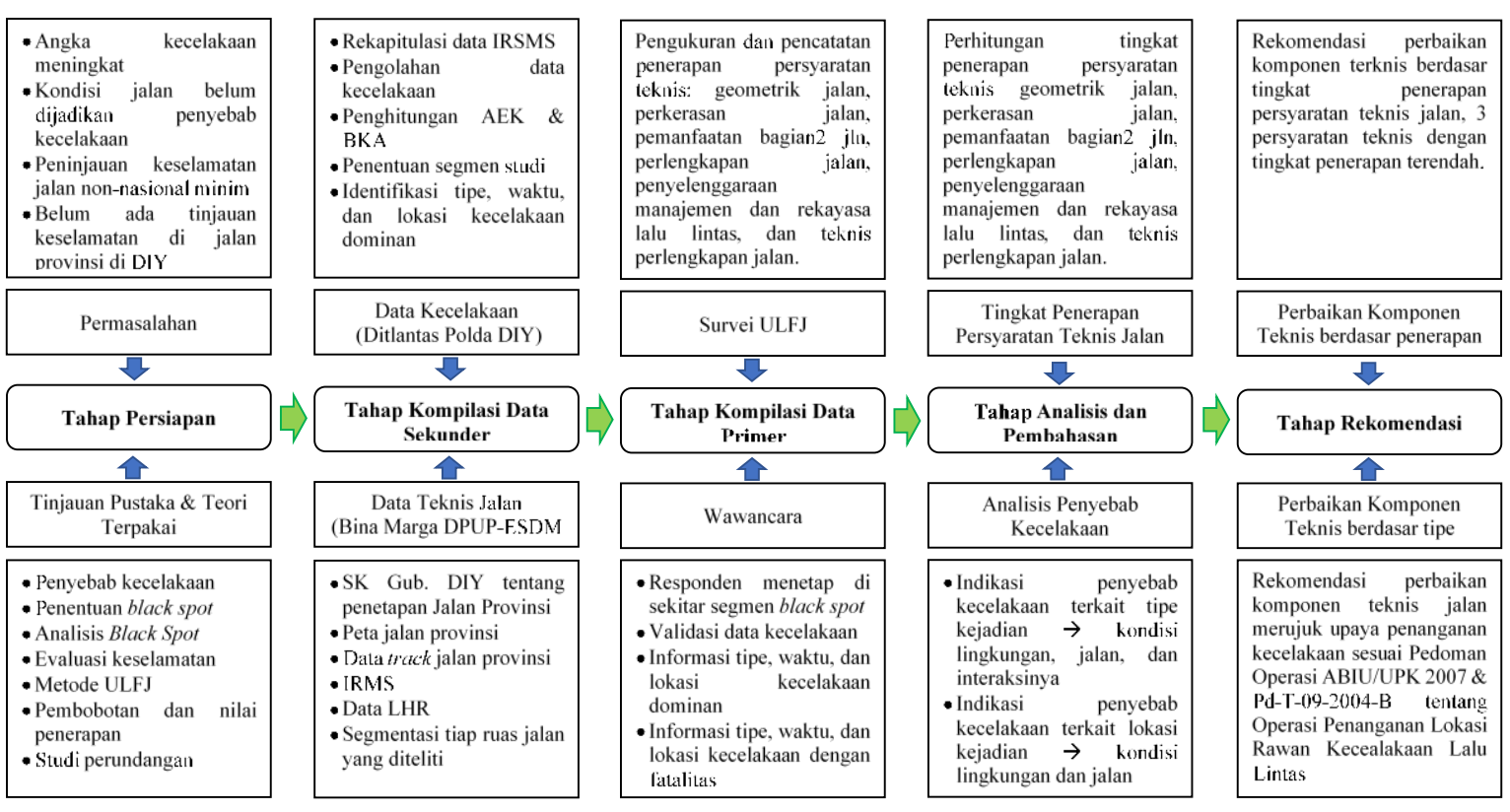

\begin{tabular}{|c|}
\hline $\begin{array}{l}\text { Perbaikan Komponen } \\
\text { Teknis berdasar tipe }\end{array}$ \\
\hline $\begin{array}{l}\text { Rekomendasi perbaikan } \\
\text { komponen teknis jalan } \\
\text { merujuk upaya penanganan } \\
\text { kecelakaan sesuai Pedoman } \\
\text { Operasi ABIU/UPK } 2007 \text { \& } \\
\text { Pd-T-09-2004-B tentang } \\
\text { Operasi Penanganan Lokasi } \\
\text { Rawan Kecealakaan Lalu } \\
\text { Lintas }\end{array}$ \\
\hline
\end{tabular}

Gambar 1 Tahapan Studi

Tahap persiapan terdiri atas 2 kegiatan utama, yaitu identifikasi sekaligus perumusan masalah dan tinjauan pustaka serta landasan teori yang dipakai dalam keseluruhan studi ini. Pada tahapan ini juga ditetapkan ruas jalan yang ditinjau, yaitu ruas jalan YogyakartaPulowatu (083), Yogyakarta-Kaliurang (084), dan Yogyakarta-Kebonagung 1 (085). Ketiga ruas jalan tersebut merupakan ruas jalan provinsi yang terletak di Kabupaten Sleman dengan kepadatan lalu lintas tertinggi.

Tahap kompilasi data sekunder merupakan tahapan pengumpulan sekaligus pengolahan data sekunder untuk menuju ke tahap berikutnya. Data sekunder yang digunakan ialah data kecelakaan lalu lintas yang diperoleh dari Ditlantas Polda DIY dan data teknis jalan yang didapat dari Bidang Bina Marga, Dinas PUP-ESDM DIY. Data kecelakaan yang digunakan adalah data Integrated Road Safety Management System (IRSMS), dalam rentang waktu 1 Januari 2018 hingga 31 Desember 2020. Data teknis jalan yang digunakan meliputi data IRMS, as built drawing, dan data track jalan provinsi di DIY.

Data kecelakaan dan data teknis jalan diolah untuk mendapatkan data kecelakaan berdasarkan titik lokasi ruas jalan. Setiap ruas jalan dibagi menjadi beberapa segmen, dengan panjang sekitar $300 \mathrm{~m}$ per segmen. Untuk setiap segmen dihitung nilai-nilai AEK dan BKA dengan menggunakan Persamaan 1 (Departemen Kimpraswil, 2004) dan Persamaan 2 (Sugiyanto, 2017):

$$
\mathrm{AEK}=12 \mathrm{M}+3(\mathrm{LB}+\mathrm{LR})+\mathrm{K}
$$


dengan:

$\mathrm{AEK}=$ angka ekivalen kecelakaan (kejadian);

$\mathrm{M}=$ jumlah korban meninggal dunia (jiwa);

$\mathrm{LB}=$ jumlah korban luka berat (jiwa);

$\mathrm{LR}=$ jumlah korban luka ringan (jiwa); dan

$\mathrm{K}=$ jumlah kecelakaan lalu lintas dengan kerugian material (kejadian).

$$
\mathrm{BKA}=\mathrm{C}+3 \sqrt{\mathrm{C}}
$$

dengan:

$\mathrm{BKA}=$ Batas Kontrol Atas; dan

$\mathrm{C} \quad=$ rerata $\mathrm{AEK}$ dalam satu ruas jalan.

Kriteria untuk suatu segmen dinyatakan sebagai black spot adalah segmen tersebut mempunyai nilai AEK bernilai sama dengan atau lebih besar dari nilai BKA. Segmen terpilih, yang menjadi fokus studi untuk tahapan berikutnya, merupakan segmen dengan nilai AEK tertinggi.

Tahap kompilasi data primer dilakukan dengan pengambilan data langsung di segmen yang ditentukan. Tahap ini terdiri atas 2 kegiatan utama, yaitu survei komponen teknis jalan yang mengacu pada ULFJ dan wawancara kepada masyarakat di sekitar lokasi (Kementerian Pekerjaan Umum, 2010). Kegiatan survei ini bertujuan untuk mengetahui tingkat penerapan persyaratan teknis jalan, yang meliputi geometrik jalan, struktur perkerasan jalan, bangunan pelengkap jalan, pemanfaatan ruang jalan, penyelenggaraan manajemen dan rekayasa lalu lintas, dan perlengkapan jalan. Persyaratan teknis jalan meliputi 30 komponen jalan yang diuji, 4 sub komponen jalan (hanya terdapat pada persyaratan teknis geometrik jalan), dan 135 fokus pengujian. Tabel isian yang digunakan sesuai dengan Petunjuk Pelaksanaan Kelaikan Fungsi Jalan No. 09/P/BM/2014, yang ditelaah oleh Mulyono (2021). Sementara itu, kegiatan wawancara kepada masyarakat sekitar bertujuan untuk memvalidasi data kecelakaan lalu lintas yang telah didapatkan, sekaligus menggali informasi yang terkait dengan kondisi jalan dan karakteristik kecelakaan lalu lintas yang terjadi.

Tahap analisis dan pembahasan terdiri atas analisis tingkat penerapan persyaratan teknis jalan dan analisis penyebab kecelakaan lalu lintas. Analisis tingkat penerapan persyaratan didapat dari hasil survei komponen teknis jalan pada tahapan sebelumnya, untuk kemudian dilihat kadar kesesuaian kondisi lapangan terhadap standar teknis perencanaan jalan. Penetapan standar teknis pada penilaian tiap komponen sesuai dengan ketentuan teknis jalan pada Peraturan Menteri PU No. 19/PRT/M/2011 untuk jalan kolektor dengan spesifikasi prasarana jalan pada jalan raya (JR) dan jalan sedang (JS), karena jalan provinsi memiliki ketentuan kelas dan fungsi sebagai JR dan JS. Tingkat penerapan persyaratan teknis didapat dengan menggunakan Persamaan 3: 


$$
\text { Tingkat penerapan }=\frac{(\text { Nilai standar }-\mid \text { Nilai standar }- \text { nilai hasil ukur } \mid)}{\text { Nilai Standar }} \times 100 \%
$$

dengan:

Tingkat penerapan $=$ kadar penerapan kondisi lapangan terhadap standar $(\%)$;

Nilai standar = nilai yang terdapat pada standar masing-masing komponen; dan

Nilai hasil ukur = nilai yang dihasilkan dari pengukuran komponen terkait.

Perhitungan tingkat penerapan tersebut berlaku untuk nilai standar teknis secara numerik, yakni batasan standar yang memiliki nilai kuantitatif. Sedangkan untuk perhitungan tingkat penerapan nilai standar non-numerik (kualitatif) atau nilai standar dengan batasan atau rentang, dapat ditentukan berdasarkan Tabel 1.

Tabel 1 Nilai Tingkat Penerapan Standar Teknis Non-Numerik dan Rentang Batasan Numerik

\begin{tabular}{cc}
\hline Hasil Uji di Lapangan & Tingkat Penerapan (\%) \\
\hline Memenuhi atau didalam batasan standar & 100,00 \\
Sebagian memenuhi & 50,00 \\
Tidak memenuhi atau diluar batasan standar & 0,00 \\
\hline
\end{tabular}

Kemudian diambil nilai rata-rata tingkat penerapan di tiap sub-komponen teknis jalan untuk memperoleh nilai tingkat penerapan komponen teknis jalan, karena dianggap tiap sub-komponen memiliki kontribusi sama dalam hal penerapan faktor keselamatan dan keamanan jalan. Analisis penyebab kecelakaan lalu lintas dilakukan dengan melihat tipe, lokasi, dan waktu kejadian kecelakaan fatal yang terjadi di segmen yang ditinjau. Tipe kecelakaan memberikan indikasi bagaimana proses terjadinya fatalitas dikaitkan dengan kondisi lalu lintas, lingkungan, dan jalan di lokasi kecelakaan. Lokasi kejadian kecelakaan lalu lintas tersebut memberikan indikasi kesalahan yang dimungkinkan menjadi penyebab kecelakaan lalu lintas di lokasi kejadian. Waktu kejadian memberikan indikasi kondisi pencahayaan dan pengaruh lalu lintas saat kejadian kecelakaan lalu lintas (Direktorat Jenderal Bina Marga, 2015).

Tahap rekomendasi menjadi tahapan terakhir studi ini. Kegiatan utama tahap ini ialah perumusan rekomendasi terhadap komponen teknis jalan yang perlu diperbaiki untuk meningkatkan keselamatan jalan. Analisis ini didasarkan 2 pertimbangan, yaitu jenis kecelakaan dominan dan tingkat penerapan persyaratan teknis jalan. Rekomendasi berdasarkan pertimbangan jenis kecelakaan dominan mengacu pada usulan penanganan dalam Pedoman ABIU/UPK tahun 2007 (Direktorat Keselamatan Transportasi Darat, 2007) dan Pedoman Pd-T-09-2004-B (Departemen Kimpraswil, 2004). Rekomendasi berdasarkan tingkat penerapan persyaratan teknis jalan mengacu pada komponen persyaratan teknis jalan yang memiliki tingkat pemenuhan rendah. 


\section{HASIL PENELITIAN DAN PEMBAHASAN}

\section{Ruas Jalan Yogyakarta-Pulowatu (083)}

Jumlah kecelakaan lalu lintas di ruas jalan ini sebanyak 119 kejadian dan terbagi dalam 31 buah segmen. Gambar 2 menjelaskan nilai AEK serta nilai BKA di tiap segmen. Enam segmen teridentifikasi sebagai black spot dengan Segmen 11 (KM 9+300 - KM 9+600) menjadi segmen terburuk. Karakteristik kecelakaan lalu lintas di Segmen 11 beserta tipe penanganannya tersaji di Tabel 2.

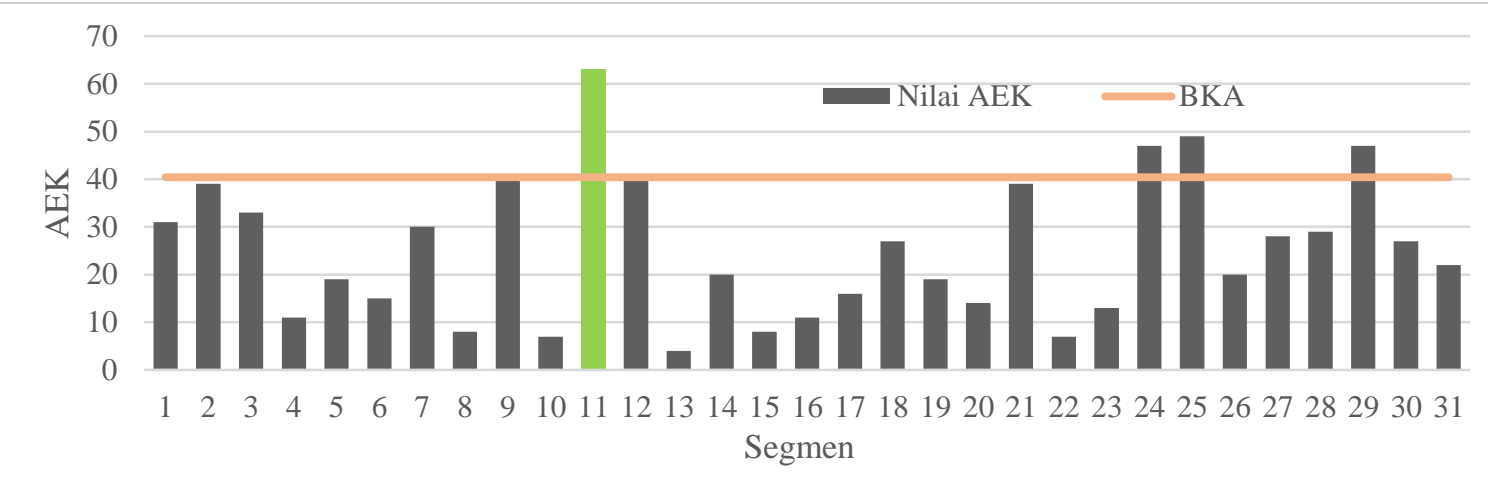

Gambar 2 Nilai AEK dan Nilai BKA Ruas Jalan Yogyakarta-Pulowatu

Hasil perhitungan tingkat penerapan persyaratan teknis jalan menunjukkan 3 persyaratan teknis jalan dengan tingkat penerapan terendah, yaitu teknis penyelenggaraan manajemen dan rekayasa lalu lintas, teknis pemanfaatan bagian-bagian jalan, dan teknis perlengkapan jalan. Gambar 3 menunjukkan rekapitulasi tingkat penerapan setiap persyaratan teknis, sementara Tabel 3 menampilkan penanganan yang perlu dilakukan pada 3 persyaratan teknis dengan nilai penerapan terendah.

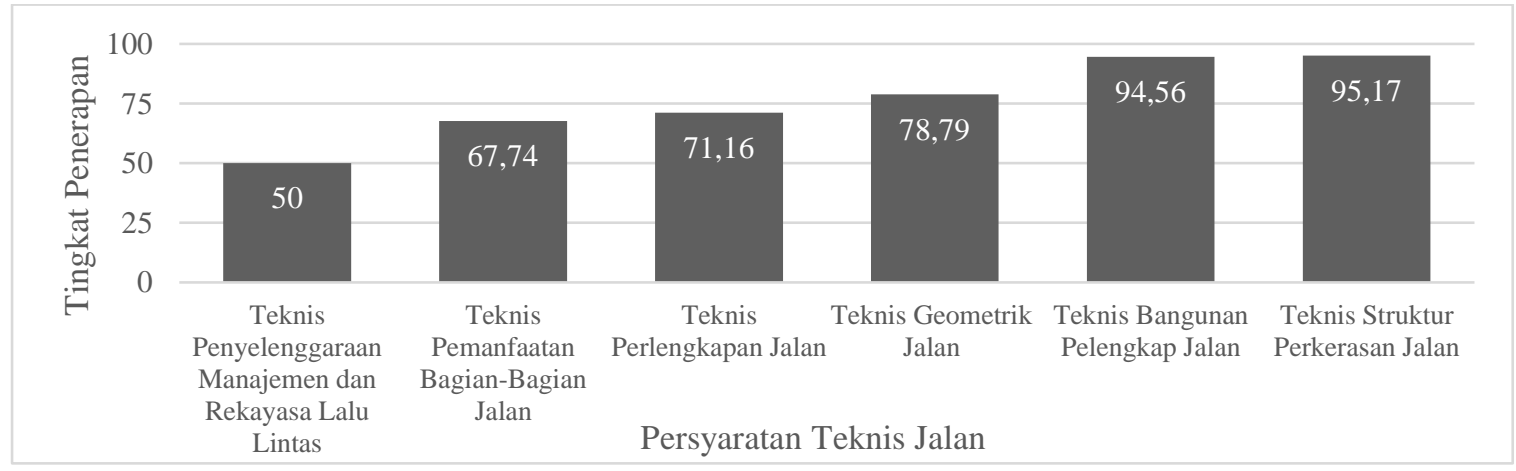

Gambar 3 Rekapitulasi Tingkat Penerapan Persyaratan Teknis di KM 9+300 - KM 9+600 Ruas Jalan Yogyakarta-Pulowatu 
Tabel 2 Karakteristik Kecelakaan Dominan beserta Rekomendasi Peningkatan Keselamatan Jalan di KM 9+300 - KM 9+600 Ruas Jalan Yogyakarta-Pulowatu

\begin{tabular}{|c|c|c|}
\hline No. & Karakteristik Kecelakaan Dominan & Rekomendasi \\
\hline \multirow[t]{4}{*}{1.} & Lokasi kecelakaan & \\
\hline & Ruas jalan bagian lurus & a. Penambahan pita penggaduh (rumble strip) \\
\hline & & $\begin{array}{l}\text { b. Penambahan paku jalan di marka tengah dan marka } \\
\text { penggaduh di tepi }\end{array}$ \\
\hline & & c. Penambahan rambu batas kecepatan \\
\hline \multirow[t]{2}{*}{2.} & Tipe kecelakaan & \\
\hline & Tabrakan saat berbelok/ menyeberang & $\begin{array}{l}\text { a. Penambahan rambu larangan } \\
\text { b. Penambahan marka lurus }\end{array}$ \\
\hline \multirow[t]{4}{*}{3.} & Waktu kecelakaan & \\
\hline & Dini hari (pukul 23.01-05.00 WIB) & a. Penerangan cukup (pemangkasan pohon rimbun) \\
\hline & & b. Penambahan pita penggaduh (rumble strip) \\
\hline & & c. Rambu peringatan elektrik \\
\hline
\end{tabular}

Tabel 3 Tingkat Penerapan Persyaratan Teknis Jalan beserta Rekomendasi Peningkatan Keselamatan Jalan di KM 9+300 - KM 9+600 Ruas Jalan Yogyakarta-Pulowatu

\begin{tabular}{|c|c|c|}
\hline No. & $\begin{array}{c}\text { Permasalahan Penerapan Persyaratan } \\
\text { Teknis Jalan }\end{array}$ & Rekomendasi \\
\hline \multirow[t]{3}{*}{1.} & $\begin{array}{l}\text { Teknis penyelenggaraan manajemen } \\
\text { dan rekayasa lalu lintas }\end{array}$ & \\
\hline & a. Ketiadaan trotoar & $\begin{array}{l}\text { Pemberian trotoar minimal di salah satu sisi jalan, dapat } \\
\text { diletakkan di atas tutup saluran jika lahan tidak } \\
\text { memungkinkan }\end{array}$ \\
\hline & $\begin{array}{l}\text { b. Jumlah rambu yang kurang dan } \\
\text { penempatan kurang sesuai }\end{array}$ & $\begin{array}{l}\text { Sebisa mungkin rambu ditempatkan di luar badan jalan } \\
\text { namun dapat tetap terlihat pengendara dengan jelas serta } \\
\text { penambahan rambu hati-hati dan peringatan sebelum } \\
\text { akses persil }\end{array}$ \\
\hline \multirow[t]{3}{*}{2.} & $\begin{array}{l}\text { Teknis pemanfaatan bagian-bagian } \\
\text { jalan }\end{array}$ & \\
\hline & $\begin{array}{l}\text { a. Lebar rumaja, rumija, dan ruwasja } \\
\text { kurang memenuhi standar }\end{array}$ & $\begin{array}{l}\text { Pembersihan gangguan, bangunan liar yang berada di } \\
\text { dalam ruang. Jika tersedia lahan dan anggaran, dapat } \\
\text { dilakukan rekonstruksi lansekap berupa relokasi pohon } \\
\text { perindang jalan ke lokasi lain di luar wilayah jalan }\end{array}$ \\
\hline & $\begin{array}{l}\text { b. Gangguan (terutama atas) } \\
\text { rumaja/rumija }\end{array}$ & $\begin{array}{l}\text { Pembersihan ranting pohon perindang dan gangguan lain } \\
\text { hingga mencapai ruang bebas setinggi minimum } 5 \text { meter } \\
\text { di atas perkerasan jalan }\end{array}$ \\
\hline \multirow[t]{3}{*}{3.} & $\begin{array}{l}\text { Teknis perlengkapan jalan } \\
\text { a. Kurangnya rambu peringatan }\end{array}$ & $\begin{array}{l}\text { Perlu penambahan rambu "peringatan" yang disertai } \\
\text { dengan papan "rawan kecelakaan" dan "peringatan } \\
\text { persimpangan tiga berganda sisi kiri" pada sisi kiri } \\
\text { sebelum akses persil dari arah Pulowatu }\end{array}$ \\
\hline & $\begin{array}{l}\text { b. Cahaya dari lampu penerangan } \\
\text { jalan terhalang lebatnya pohon }\end{array}$ & $\begin{array}{l}\text { Pemangkasan pohon atau relokasi pohon ke tempat lain } \\
\text { selain wilayah jalan }\end{array}$ \\
\hline & c. Ketiadaan trotoar & $\begin{array}{l}\text { Penyediaan trotoar yang dilengkapi perlindungan pejalan } \\
\text { kaki dan yang mampu mengakomodasi penyandang } \\
\text { disabilitas }\end{array}$ \\
\hline
\end{tabular}

Hazard utama di segmen ini ialah pohon perindang yang berada tepat di tepi perkerasan beraspal, yang dapat mengurangi ruang bebas berkendara sekaligus mengurangi paparan penerangan lampu jalan. Prioritas penanganan keselamatan jalan yang dibutuhkan segmen ini adalah relokasi hazard tepi jalan pada Ruang Milik Jalan (Rumija) sekaligus 
pembuatan pagar pengaman tepi (guard rail), karena adanya sungai terbuka di sisi timur jalan. Contoh rekomendasi ini ditunjukkan pada Gambar 4.

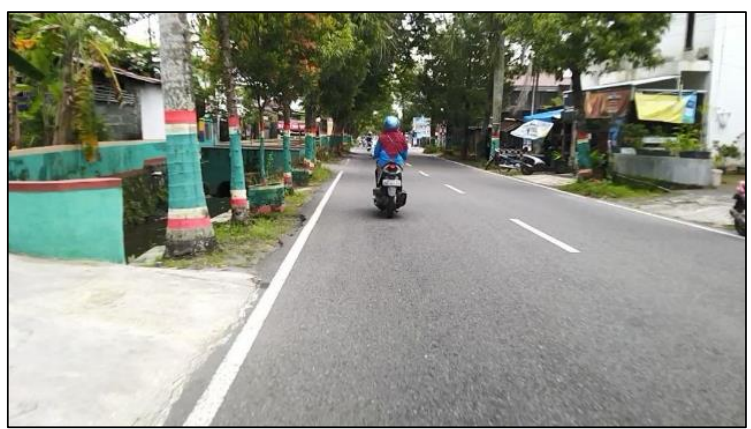

(a) Kondisi Awal di Lapangan

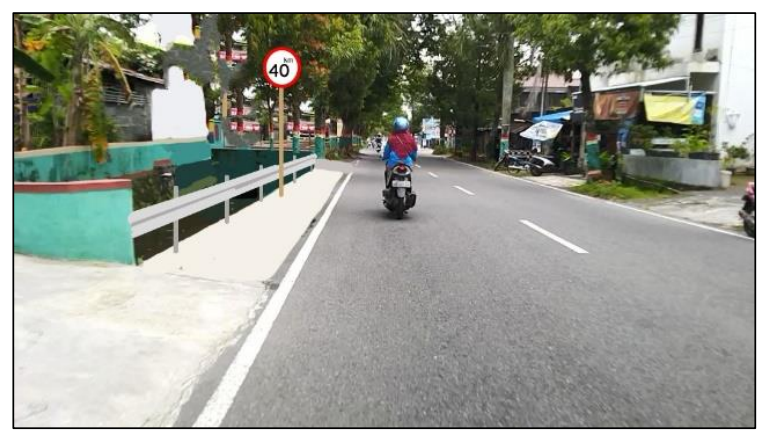

(b) Kondisi Rencana Penanganan

Gambar 4 Contoh Penanganan KM 9+300 - KM 9+600 Ruas Jalan Yogyakarta-Pulowatu;

\section{Ruas Jalan Yogyakarta-Kaliurang (084)}

Jumlah kecelakaan lalu lintas di ruas jalan ini adalah 214 kejadian dan terbagi dalam 57 buah segmen. Pada Gambar 5 dapat dilihat nilai AEK serta nilai BKA di tiap segmen. Tiga belas segmen teridentifikasi sebagai black spot dengan Segmen 20 (KM 12+300 - KM 12+600) merupakan segmen terburuk. Karakteristik kecelakaan di Segmen 20 beserta tipe penanganannya disajikan pada Tabel 4.

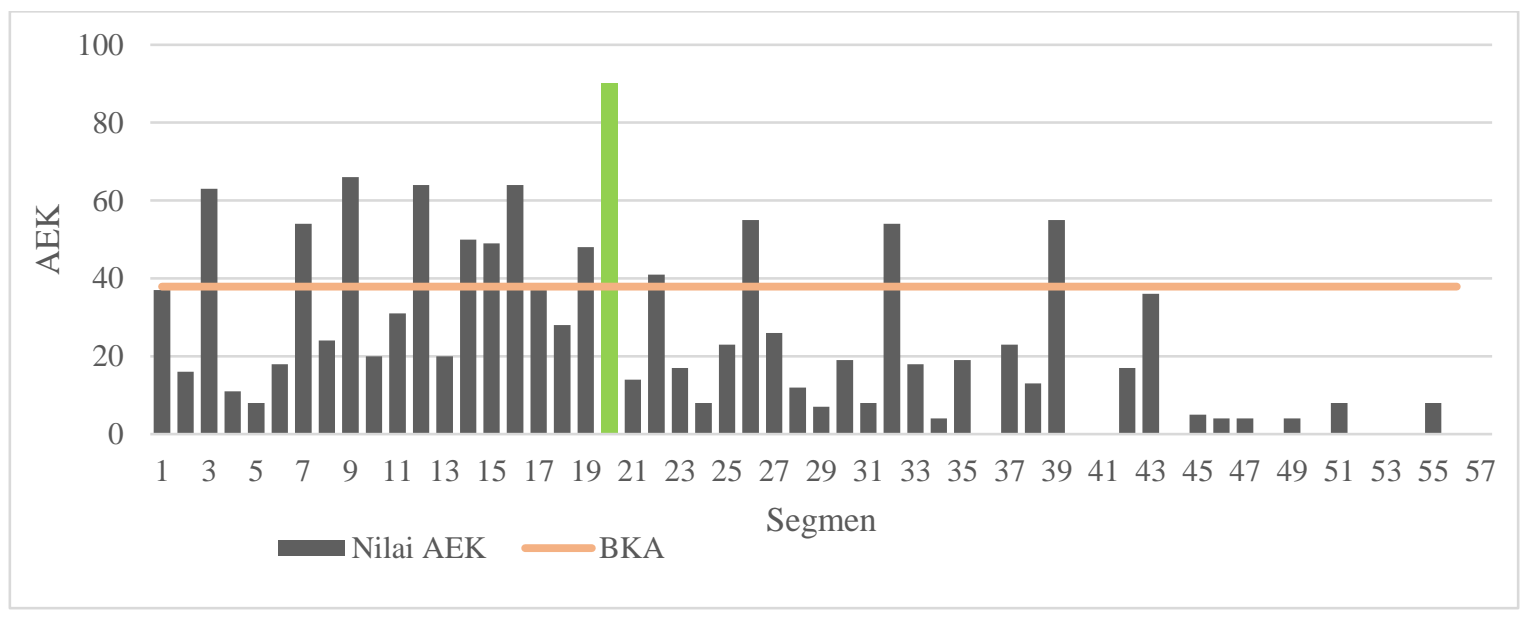

Gambar 5 Nilai AEK dan Nilai BKA Ruas Jalan Yogyakarta-Kaliurang

Hasil analisis menunjukkan 3 persyaratan teknis jalan dengan tingkat penerapan terendah, yang meliputi teknis penyelenggaraan manajemen dan rekayasa lalu lintas, teknis pemanfaatan bagian-bagian jalan, dan teknis perlengkapan jalan. Gambar 6 menunjukkan rekapitulasi tingkat penerapan setiap persyaratan teknis, sementara Tabel 5 menampilkan penanganan yang perlu dilakukan di 3 persyaratan teknis dengan nilai penerapan terendah. 


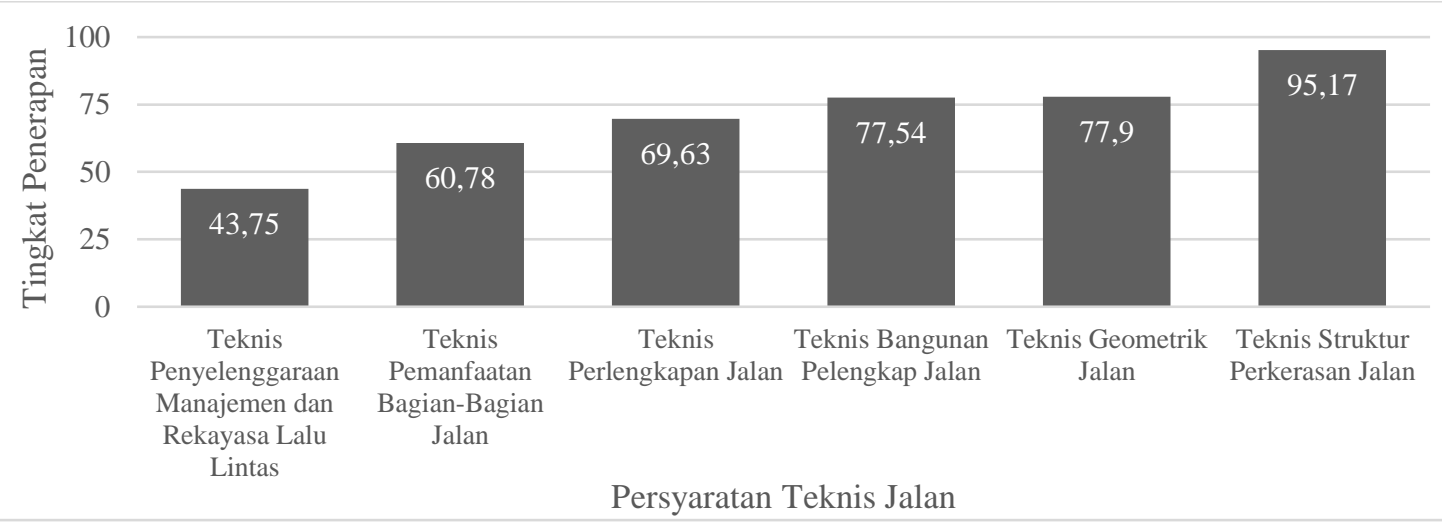

Gambar 6 Rekapitulasi Tingkat Penerapan Persyaratan Teknis di KM 12+300 - KM 12+600 di Ruas Jalan Yogyakarta-Kaliurang

Tabel 4 Karakteristik Kecelakaan Dominan beserta Rekomendasi Peningkatan Keselamatan Jalan di KM 12+300 - KM 12+600 Ruas Jalan Yogyakarta-Kaliurang

\begin{tabular}{|c|c|c|}
\hline No. & Karakteristik Kecelakaan Dominan & Rekomendasi \\
\hline \multirow[t]{4}{*}{1.} & Lokasi kecelakaan & \\
\hline & Ruas jalan bagian lurus & a. Penambahan pita penggaduh (rumble strip) \\
\hline & & $\begin{array}{l}\text { b. Penambahan paku jalan di marka tengah dan marka } \\
\text { penggaduh di tepi }\end{array}$ \\
\hline & & c. Penambahan rambu batas kecepatan $40 \mathrm{~km} / \mathrm{jam}$ \\
\hline \multirow[t]{6}{*}{2.} & Tipe kecelakaan & \\
\hline & Tabrakan saat berbelok/menyeberang & a. Penambahan rambu larangan \\
\hline & & b. Pembuatan rintangan dalam hal ini median jalan \\
\hline & & c. Penggantian marka menjadi marka lajur \\
\hline & & d. Pembuatan zona tempat mendahului \\
\hline & & $\begin{array}{l}\text { e. Penyesuaian lebar lajur untuk memberi ruang yang } \\
\text { cukup untuk kendaraan bermanuver }\end{array}$ \\
\hline \multirow[t]{2}{*}{3.} & Waktu kecelakaan & \\
\hline & Pagi hari (pukul 05.01-09.00 WIB) & $\begin{array}{l}\text { a. Penambahan rambu batas kecepatan } 40 \mathrm{~km} / \mathrm{jam} \\
\text { b. Penambahan pita penggaduh (rumble strip) }\end{array}$ \\
\hline
\end{tabular}

Tabel 5 Tingkat Penerapan Persyaratan Teknis Jalan beserta Rekomendasi Peningkatan Keselamatan Jalan di KM 12+300 - KM 12+600 Ruas Jalan Yogyakarta-Kaliurang

\begin{tabular}{|c|c|c|}
\hline No. & $\begin{array}{c}\text { Permasalahan Penerapan Persyaratan } \\
\text { Teknis Jalan }\end{array}$ & Rekomendasi \\
\hline \multirow[t]{4}{*}{1.} & $\begin{array}{l}\text { Teknis penyelenggaraan manajemen } \\
\text { dan rekayasa lalu lintas }\end{array}$ & \\
\hline & a. Ketiadaan trotoar & $\begin{array}{l}\text { Pembuatan trotoar di kedua sisi jalan, dapat diletakkan di } \\
\text { atas tutup saluran jika lahan tidak memungkinkan }\end{array}$ \\
\hline & $\begin{array}{l}\text { b. Ketiadaan alat/tempat } \\
\text { penyeberangan }\end{array}$ & $\begin{array}{l}\text { Pembuatan zona penyeberangan berupa pelican crossing } \\
\text { pada lokasi di segmen ini yang memiliki volume } \\
\text { penyeberang jalan yang ramai (di daerah sebelum/setelah } \\
\text { akses persil) }\end{array}$ \\
\hline & $\begin{array}{l}\text { c. Jumlah rambu yang kurang dan } \\
\text { penempatan kurang sesuai }\end{array}$ & $\begin{array}{l}\text { Sebisa mungkin rambu ditempatkan di luar badan jalan } \\
\text { namun tetap terlihat pengendara dengan jelas serta } \\
\text { penambahan rambu hati-hati dan peringatan sebelum } \\
\text { akses persil }\end{array}$ \\
\hline
\end{tabular}


Tabel 5 Tingkat Penerapan Persyaratan Teknis Jalan beserta Rekomendasi Peningkatan Keselamatan Jalan di KM 12+300 - KM 12+600 Ruas Jalan Yogyakarta-Kaliurang (Lanjutan)

\begin{tabular}{|c|c|c|}
\hline No. & $\begin{array}{c}\text { Permasalahan Penerapan Persyaratan } \\
\text { Teknis Jalan }\end{array}$ & Rekomendasi \\
\hline \multirow[t]{3}{*}{2.} & $\begin{array}{l}\text { Teknis pemanfaatan bagian-bagian } \\
\text { jalan }\end{array}$ & \\
\hline & $\begin{array}{l}\text { a. Lebar rumaja, rumija, dan ruwasja } \\
\text { kurang memenuhi standar }\end{array}$ & $\begin{array}{l}\text { Pembersihan gangguan, bangunan liar (termasuk struktur } \\
\text { reklame) yang berada di dalam ruang. }\end{array}$ \\
\hline & $\begin{array}{l}\text { b. Gangguan (terutama atas) } \\
\text { rumaja/rumija }\end{array}$ & $\begin{array}{l}\text { Pembersihan ranting pohon perindang dan gangguan lain } \\
\text { hingga mencapai ruang bebas setinggi minmum } 5 \text { meter } \\
\text { di atas perkerasan jalan. }\end{array}$ \\
\hline \multirow[t]{4}{*}{3.} & Teknis perlengkapan jalan & \\
\hline & $\begin{array}{l}\text { a. Ketiadaan tempat parkir yang } \\
\text { memadai }\end{array}$ & $\begin{array}{l}\text { Perlu ada tempat parkir di tiap tempat aktivitas } \\
\text { perekonomian warga yang memiliki kapasitas sesuai } \\
\text { dengan kebutuhan kendaraan yang akan parkir. }\end{array}$ \\
\hline & b. Kurangnya rambu peringatan & $\begin{array}{l}\text { Perlu penambahan rambu "peringatan" yang disertai } \\
\text { dengan papan "rawan kecelakaan" dan "peringatan } \\
\text { persimpangan tiga" pada sisi kiri sebelum akses persil. }\end{array}$ \\
\hline & c. Ketiadaan trotoar & $\begin{array}{l}\text { Penyediaan trotoar yang dilengkapi perlindungan pejalan } \\
\text { kaki dan yang mampu mengakomodasi penyandang } \\
\text { disabilitas }\end{array}$ \\
\hline
\end{tabular}

Suatu kebutuhan keselamatan jalan di segmen ini adalah pemberian zona penyeberangan sekaligus pembuatan trotoar untuk memfasilitasi aktivitas pejalan kaki yang cukup ramai pada saat tertentu. Hal tersebut diperkuat oleh keterangan warga sekitar yang pernah menjadi korban kecelakaan dan kehilangan anggota keluarga saat menyeberang di jalan ini. Zona penyeberangan direkomendasikan menggunakan pedestrian light controlled (pelicon) crossing karena kecenderungan pengendara memacu kendaraan dengan kecepatan tinggi saat melintasi segmen ini, terutama saat pagi dan sore hari. Contoh visualiasai rekomendasi dapat dilihat pada Gambar 7.

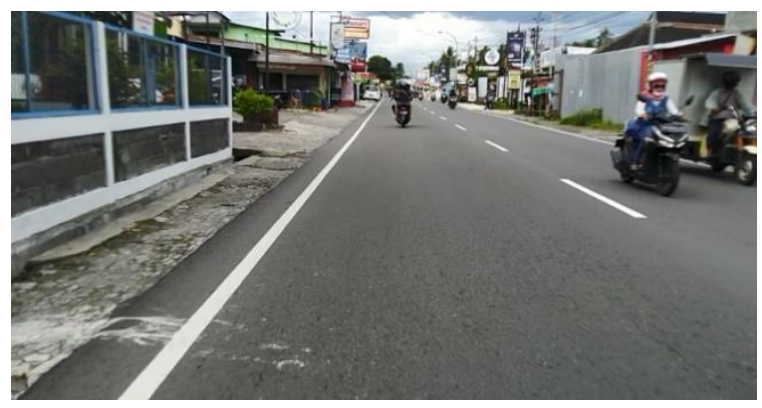

(a) Kondisi Awal di Lapangan

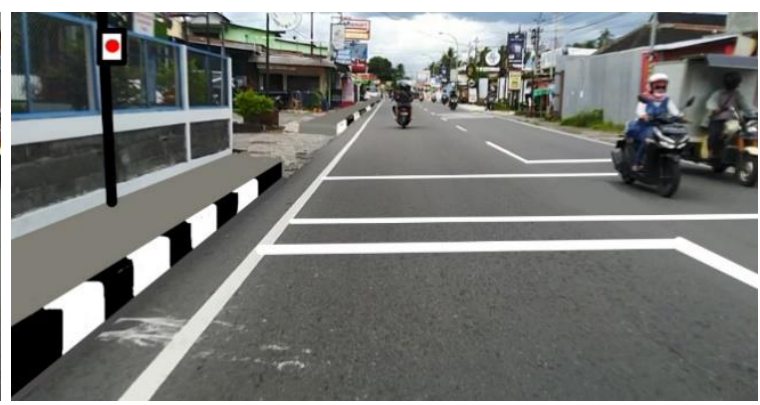

(b) Kondisi Rencana Penanganan

Gambar 7 Contoh Penanganan KM 12+300 - KM 12+600 Ruas Jalan Yogyakarta-Kaliurang

\section{Ruas Jalan Yogyakarta-Kebonagung 1 (085)}

Jumlah kecelakaan lalu lintas di ruas jalan ini adalah 248 kejadian dan terbagi dalam 42 buah segmen. Gambar 8 menunjukkan nilai AEK serta nilai BKA di tiap segmen. Terdapat 7 segmen teridentifikasi sebagai black spot dengan Segmen 23 (KM 11+700 - KM 12+000) merupakan segmen terburuk. Karakteristik kecelakaan lalu lintas di Segmen 23 beserta tipe penanganannya dapat dilihat pada Tabel 6 . 


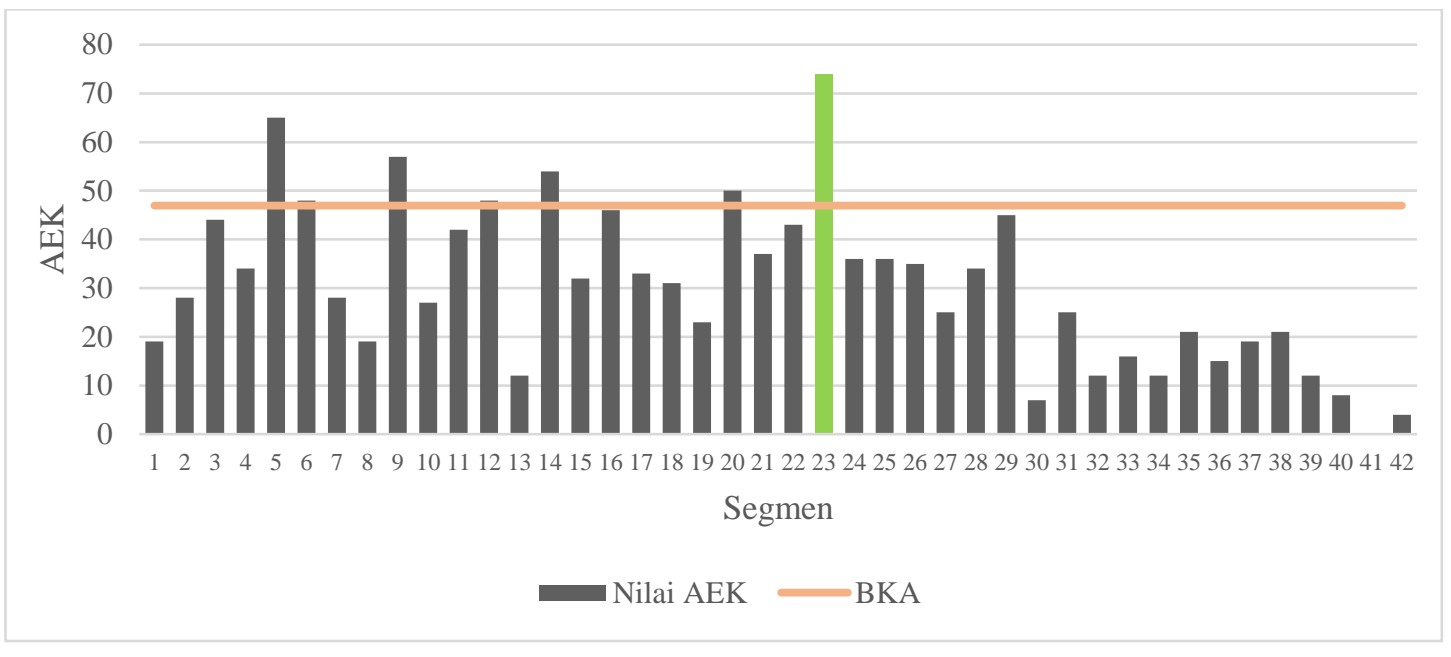

Gambar 8 Nilai AEK dan Nilai BKA Ruas Jalan Yogyakarta-Kebonagung 1

Tabel 6 Jenis dan Tipe Kecelakaan Dominan beserta Usulan Peningkatan Keselamatan Jalan pada Black Spot di Ruas Jalan Yogyakarta-Kebonagung 1

\begin{tabular}{cll}
\hline No. & \multicolumn{1}{c}{ Jenis dan Tipe Kecelakaan } & \multicolumn{1}{c}{ Usulan Peningkatan Keselamatan } \\
\hline 1. $\quad$ Lokasi kecelakaan & a. Penambahan pita penggaduh (rumble strip) \\
& $\begin{array}{l}\text { b. Penambahan paku jalan di marka tengah dan marka } \\
\text { penggaduh di tepi }\end{array}$ \\
& c. Penambahan rambu batas kecepatan \\
2. Tipe kecelakaan & a. Penambahan rambu larangan \\
Tabrakan saat berbelok/menyeberang & b. Pembuatan median \\
3. Waktu kecelakaan & a. Penambahan rambu batas kecepatan \\
& b. Penambahan pita pengaduh (rumble strip)
\end{tabular}

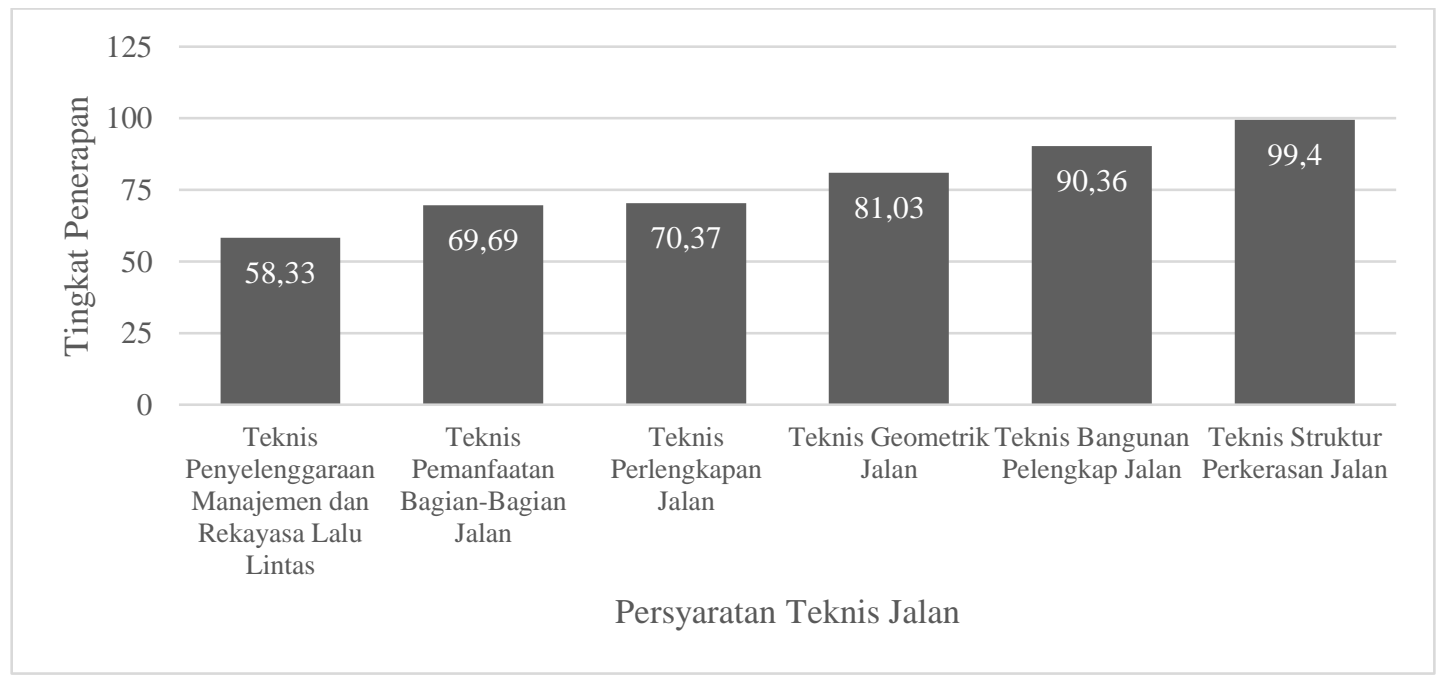

Gambar 9 Rekapitulasi Tingkat Penerapan Persyaratan Teknis di KM 11+700 - KM KM 12+000 di Ruas Jalan Yogyakarta-Kebonagung 1 
Terdapat 3 persyaratan teknis jalan dengan tingkat penerapan terendah, yaitu teknis penyelenggaraan manajemen dan rekayasa lalu lintas, teknis pemanfaatan bagian-bagian jalan, dan teknis perlengkapan jalan. Gambar 9 menunjukkan rekapitulasi tingkat penerapan setiap persyaratan teknis, sementara Tabel 7 menampilkan penanganan yang perlu dilakukan di 3 persyaratan teknis dengan nilai penerapan terendah.

Tabel 7 Tingkat Penerapan Persyaratan Teknis Jalan beserta Usulan Peningkatan Keselamatan Jalan di KM 11+700 - 12+000 di Ruas Jalan Yogyakarta - Kebonagung 1

\begin{tabular}{|c|c|c|}
\hline No. & $\begin{array}{l}\text { Permasalahan Tiap Persyaratan } \\
\text { Teknis Jalan }\end{array}$ & Usulan Peningkatan Keselamatan \\
\hline \multirow[t]{3}{*}{1.} & $\begin{array}{l}\text { Teknis penyelenggaraan manajemen } \\
\text { dan rekayasa lalu lintas }\end{array}$ & \\
\hline & a. Ketiadaan tempat penyeberangan & $\begin{array}{l}\text { Pemberian tempat penyeberangan atau zebra cross } \\
\text { terutama pada lokasi dengan aktivitas penyeberang jalan } \\
\text { yang tinggi }\end{array}$ \\
\hline & b. Jumlah rambu yang kurang & $\begin{array}{l}\text { Penambahan rambu hati-hati dan peringatan sebelum } \\
\text { akses persil }\end{array}$ \\
\hline 2. & $\begin{array}{l}\text { Teknis pemanfaatan bagian jalan } \\
\text { a. Lebar rumaja, rumija, dan ruwasja } \\
\text { kurang memenuhi standar }\end{array}$ & $\begin{array}{l}\text { Pembersihan gangguan, bangunan liar yang berada di } \\
\text { dalam ruang }\end{array}$ \\
\hline & b. Gangguan rumaja/rumija & $\begin{array}{l}\text { Memastikan struktur selain konstruksi jalan berada di atas } \\
5 \text { meter dan dibawah } 1,5 \text { meter dari jalan }\end{array}$ \\
\hline 3. & $\begin{array}{l}\text { Teknis perlengkapan jalan } \\
\text { a. Kurangnya rambu peringatan dan } \\
\text { tidak adanya parkir yang memadai }\end{array}$ & $\begin{array}{l}\text { Penambahan rambu "peringatan" disertai dengan papan } \\
\text { "rawan kecelakaan" dan "zona penyeberangan, serta } \\
\text { penyediaan tempat parkir yang memadai di luar bahu jalan }\end{array}$ \\
\hline
\end{tabular}

Penanganan masalah keselamatan di segmen ini dapat dilakukan dengan penambahan rambu, marka, zebra cross, serta rumble strip pada daerah pendekat akses masuk jalan lingkungan, serta dilakukan peningkatan kapasitas jalan, karena lahan masih memungkinkan. Penanganan ini dapat dilihat pada Gambar 10.

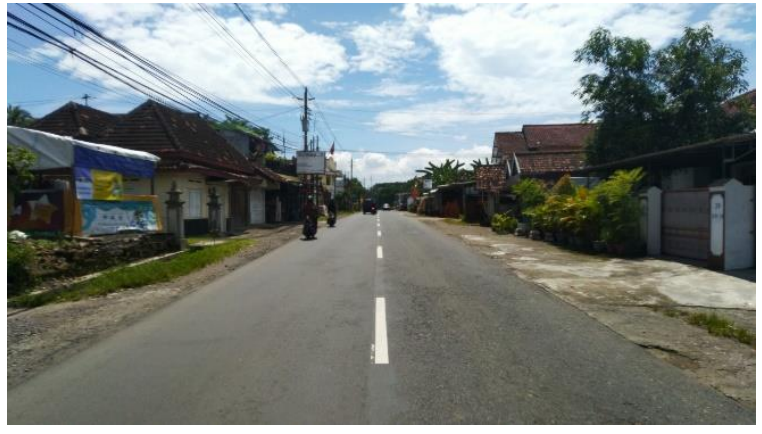

(a) Kondisi Awal di Lapangan

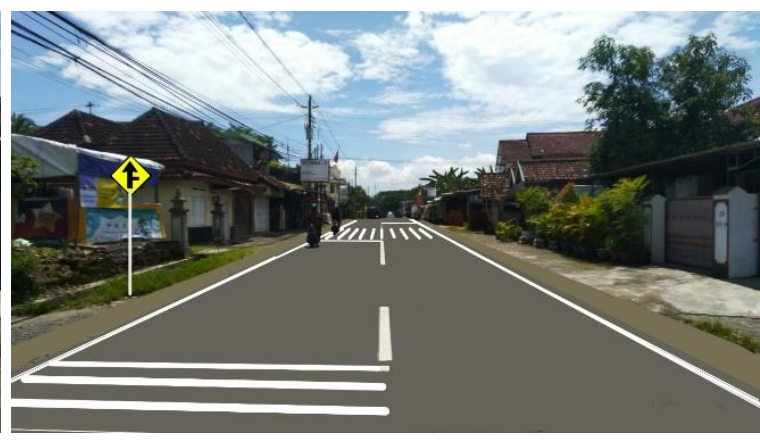

(b) Kondisi Rencana Penanganan

Gambar 10 Contoh Penanganan KM 11+700 - KM 12+000 di Ruas Jalan Yogyakarta-Kebonagung 1

\section{KESIMPULAN}

Pada studi ini terlihat bahwa seluruh lokasi atau tipe geometrik segmen terburuk jalan provinsi di Kabupaten Sleman berada di segmen dengan geometrik lurus. Sedangkan tipe 
dan waktu kecelakaan lalu lintas bervariasi. Jumlah dan lokasi titik rawan kecelakaan pada ruas jalan yang diteliti adalah: (1) di ruas jalan Yogyakarta-Pulowatu berjumlah 6 segmen black spot, dengan Segmen 11 (KM 9+300 - KM 9+600) merupakan segmen terburuk, (2) di ruas jalan Yogyakarta-Kaliurang berjumlah 13 segmen black spot, dengan Segmen 20 (KM 12+300 - KM 12+600) merupakan segmen terburuk, dan (3) ruas jalan YogyakartaKebonagung 1 berjumlah 6 segmen black spot, dengan Segmen 23 (KM 11+700KM12+000) merupakan segmen terburuk.

Tingkat penerapan persyaratan teknis jalan yang paling rendah adalah teknis penyelenggaraan manajemen dan rekayasa lalu lintas, teknis pemanfaatan bagian-bagian jalan, dan teknis perlengkapan jalan. Rekomendasi untuk peningkatan atau perbaikan komponen infrastruktur jalan, untuk meningkatan keselamatan, meliputi penambahan rumble strip atau pita penggaduh, penambahan rambu termasuk rambu elektronik, pembuatan trotoar, relokasi hazard di dalam Rumija, penambahan tempat penyeberangan dan tempat parkir yang memadai, dan penambahan zona dilarang menyiap sekaligus zona diperbolehkan menyiap.

\section{UCAPAN TERIMA KASIH}

Ucapan terima kasih disampaikan kepada Pusat Pembinaan, Pendidikan, dan Pelatihan Perencana (Pusbindiklatren) Bappenas yang telah memberikan pendanaan untuk studi ini serta kepada tim survei atas dukungan yang diberikan dalam pengumpulan data.

\section{DAFTAR PUSTAKA}

Badan Perencanaan dan Pembangunan Daerah Provinsi Daerah Istimewa Yogyakarta (Bappeda DIY). 2020. Aplikasi Dataku Daerah Istimewa Yogyakarta; Elemen: Data Kecelakaan dan Pelanggaran Lalu Lintas. (Online), (http://bappeda.jogjaprov. go.id/dataku/data_dasar/cetak/548-data-kecelakaan-dan-pelanggaran-lalu-lintas, diakses 27 Desember 2020).

Departemen Permukiman dan Prasarana Wilayah (Kimpraswil). 2004. Pedoman Konstruksi dan Bangunan Nomor Pd T-09-2004-B: Penanganan Lokasi Rawan Kecelakaan Lalu Lintas. Jakarta.

Direktorat Jenderal Bina Marga. 2015. Petunjuk Pelaksanaan Kelaikan Fungsi Jalan No. 09/P/BM/2014. Kementerian Pekerjaan Umum. Jakarta.

Direktorat Keselamatan Transportasi Darat. 2007. Pedoman Operasi Accident Blackspot Investigation Unit/ Unit Penelitian Kecelakaan Lalulintas (ABIU/UPK). Direktorat Jenderal Perhubungan Darat. Departemen Perhubungan. Jakarta.

Kementerian Pekerjaan Umum. 2010. Peraturan Menteri Pekerjaan Umum Nomor 11/PRT/M/2010 tentang Tata Cara dan Persyaratan Uji Laik Fungsi Jalan, Jakarta. 
Mulyono, A. T. 2021. Uji Laik Jalan Berkeselamatan dan Berkepastian Hukum. Yogyakarta: Gadjah Mada University Press.

Pemerintah Republik Indonesia. 2004. Undang-Undang Republik Indonesia Nomor 38 Tahun 2004 tentang Jalan. Jakarta.

Sugiyanto, G. dan Fadli, A. 2017. Identifikasi Lokasi Rawan Kecelakaan Lalu Lintas (Black Spot) di Kabupaten Purbalingga, Jawa Tengah. Jurnal Teknik Sipil \& Perencanaan, 19 (2): 128-135. 